УДК 323,2 : 340.131](477)

DOI: $10.34132 /$ pard2021.13.01

\title{
НОРМАТИВНО-ПРАВОВІ ЗАСАДИ РОЗВИТКУ ГРОМАДЯНСЬКОГО СУСПІЛЬСТВА В УКРАЇНІ
}

Акімова T. Ю., канд. наук 3 держ. упр., доцент, Інститут державного управління, Чорноморський національний університет імені Петра Могили, м. Миколаїв, Україна.

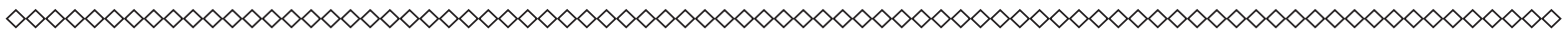

У статті досліджуються питання нормативно-правового забезпечення розвитку громадянського суспільства в Україні. Розглянуті важливі документи, які сприяли розвитку громадянського суспільства.

Розкрито сутність поняття громадянське суспільство. Розглянуто сучасні існуючі підходи до розуміння громадянського суспільства, а саме: иирокий підхід, прихильники якого сприймають громадянське суспільство як певний етап розвитку будь-якого суспільства та підхід, який розглядає громадянське суспільство як комплекс усіх недержавних сочіальних відносин. Зазначено основні складові в системі громадянського суспільства та основні ролі організацій громадянського суспільства, а саме: надання послуг у сфері розвитку, вплив на політику шляхом діалогу та адвокації, захист прав людини та демократизачія.

Зазначено, щзо стрімкий розвиток громадянського суспільства в Україні почався після Револючії Гідності 2013-14 роках. Прикладом громадянської інічіативи, щчо виникла під час Революиї Гідності став Реанімачійний пакет реформ. Визначено, щзо Топ-3 завдань громадських організацій в Україні були названі контроль над урядом, громадянська освіта, підтримка та стимулювання реформ.

У статті досліджено прочес розвитку громадянського суспільства в контексті законодавчого забезпечення. Розглянуто, Стратегію сталого розвитку «Украӥна-2020», Національну економічну стратегію на період до 2030 року», Національну стратегію спри- 
яння розвитку громадянського суспільства в Україні на 2021-2026 роки та ін. Доведено, щуо серед основних напрямів роботи прослідковується важливість налагодження комунікації з інститутами громадянського суспільства та інформачійне забезпечення, зокрема отримання зворотного зв'язку. Головною передумовою процесу розвитку громадянського суспільства визначений суспільний договір між владою, бізнесом та громадянським суспільством, де кожна сторона має свою зону відповідальності

Ключові слова: публічне управління, громадянське суспільство, правові механізми, організації громадянського суспільства.

Постановка проблеми у загальному вигляді. Громадянське суспільство $є$ невід'ємною основою розвитку та національної згуртованості. У Порядку денному для сталого розвитку на період до 2030 року чітко висловлено необхідність об'єднання організацій громадянського суспільства для впровадження та досягнення цілей сталого розвитку. Організації громадянського суспільства виконують важливі ролі: надають послуги у сфері розвитку, впливають на політику шляхом діалогу та адвокації, сприяють i захищають права людини та демократизацію. Таким чином, відіграють певну роль у співпраці в галузі розвитку, звісно поки така співпраця існує.

Закріплення основних засад та сутнісних характеристик громадянського суспільства відбувається у нормативно-правових актах, які представляють собою фундаментальну основу для функціонування, організації та подальшого стабільного розвитку громадянського суспільства в Україні.

Аналіз останніх досліджень і публікацій. Проблематика статті висвітлюється у працях таких науковців, як: М. Яблонський, П. Вознюк, Д Горєлов, С. Соляр, громадянське суспільство в Угоді про асоціацію між Україною та СС досліджували I. Солоненко, Р. Хорольський, Н. Шаповалова, М. Лациба, проблеми взаємодії держави та інститутів громадянського суспільства розглянуто у працях І. Кресіна, О. Скрипнюк, А. Коваленко та інших. 
Формулювання цілей статті (постановка задання). Метою статті $є$ дослідження питання нормативно-правового забезпечення розвитку громадянського суспільства в Україні.

Виклад основного матеріалу дослідження. Громадянське суспільство є одним із важливих структурних елементів розвитку України як сильної, незалежної, демократичної держави. Наявність впорядкованої та добре функціонуючої системи громадянського суспільства істотно впливає на управління державними справами, організацію та ефективність вирішення питань місцевого значення, а також, впливає на створення соціальної і правової держави.

Громадянське суспільство часто характеризують як одну з трьох сфер діяльності, поряд з урядом та приватним сектором. Воно було визначене як «сфера асоціацій людей, які об'єднані добровільно», в межах якої індивіди здійснюють колективні дії для вирішення спільних потреб, ідей та інтересів, які вони спільно визначили [22]. Перш за все, громадянське суспільство відіграє вирішальну роль у «представництві громади». Воно забезпечує колективне представлення цілей, проектів або проблем, які виходять за межі «загальних інтересів», якими опікуються державні органи влади. По-друге, організації громадянського суспільства представляють не свої «власні» інтереси, а інтереси своєї громади; вони виконують роль посередника [24].

Тобто, громадянське суспільство за своєю сутністю представляє собою взаємодію громадян, котрі проживають на певній території, які мають комплекс прав та обов'язків, що дозволяють їм брати участь у розвитку держави. Тобто, основними мотивами створення громадянського суспільства є можливість самоорганізації населення, діяльність якого буде направлена виключно на покращення рівня життя людей та функціонального механізму держави. Типовими прикладами прояву активності громадянського суспільства можна вважати утворення громадських об'єднань та створення громадських організацій.

Сучасні існуючі підходи до розуміння громадянського суспільства можна структурувати на такі основні групи:

1. Широкий підхід, прихильники якого сприймають громадянське суспільство як певний етап розвитку будь-якого суспільства. 
При такому підході «цивілізованість» стає характерною рисою всього суспільства в цілому, включаючи державу як одну з невід’ємних частин цього суспільства [16].

2. Підхід, який розглядає громадянське суспільство як комплекс усіх недержавних соціальних відносин. При такому підході громадянське суспільство претендує на природну форму протистояння владі [5], воно виступає як розвинута система соціальних відносин, підкріплена недержавними відносинами, що реалізуються в діяльності інститутів громадянського суспільства - політичних партій, громадських організацій, ініціатив, громадських рухів, недержавних 3МI і мають вирішальний вплив на діяльність органів державної влади та протидіють їй у разі посилення авторитарних тенденцій.

Основними же складовими в системі громадянського суспільства прийнято вважати інститути, відносини між людьми, діяльність людей, соціальний статус та соціальну стратифікацію населення, правове регулювання, наявність держави і вплив фактору інформації.

Загалом, варто відзначити, що громадянське суспільство сприяє розвитку та зміцненню демократичних інститутів, передачі державою своїх владних повноважень певним громадським організаціям, органам самоврядування. Суб〉єкти, що входять в таку соціальну сферу, незалежні один від одного і взаємодіють як вільні і рівні партнери. Сам процес становлення громадянського суспільства складний і суперечливий та відрізняється тривалістю. Можна сказати, що цей процес не завершений ні в одній з існуючих країн, однак, всі країни прагнуть до побудови стабільності в цьому аспекті. Формування громадянського суспільства - одна 3 необхідних умов просування України по шляху проведення економічних, політичних і правових реформ, становлення правової держави в рамках їі участі у європейській спільноті.

Стрімкий розвиток громадянського суспільства в Україні почався після Революції Гідності 2013-14 роках. Прикладом громадянської ініціативи, що виникла під час Революції Гідності (або Майдану), був Реанімаційний пакет реформ, який об〉єднує різні 
неурядові організації з метою моніторингу та стимулювання реформ у країні. Він служить координаційним центром між громадянським суспільством та урядом при розробці законопроектів та лобістських реформах у парламенті.

Станом на квітень 2019 року до коаліції Реанімаційного пакету реформ входили 83 громадські організації , які працювали у 22 експертних групах у конкретних сферах, починаючи від антикорупційних, судових та медійних реформ та закінчуючи податковою політикою, культурою та охороною навколишнього середовища. Топ-3 завдань громадських організацій в Україні були названі контроль над урядом, громадянська освіта, підтримка та стимулювання реформ.

Після Революції Гідності, упродовж 2014-2018 років, розроблено та ухвалено низку важливих нормативно-правових актів, які сприяли розвитку громадянського суспільства. Указом Президента України від 12.01.2015 № 5/2015 ухвалено Стратегію сталого розвитку «Україна-2020». Метою Стратегії було визначено впровадження європейських стандартів життя та вихід України на провідні позиції світу [17]. 3 цією метою було визначено чотири основні вектори розвитку, в рамках яких було заплановано впровадження 62 реформ та програм розвитку держави: «вектор розвитку», «вектор безпеки», «вектор відповідальності» та «вектор гордості».

Головною передумовою реалізації Стратегії був визначений суспільний договір між владою, бізнесом та громадянським суспільством, де кожна сторона має свою зону відповідальності [17]. Завданням влади було провести реформи, таким чином забезпечити баланс інтересів між громадянським суспільством, державою i бізнесом, прозоро та якісно працювати та гарантувати дотримання прав людини. Відповідальністю бізнесу - підтримувати та розвивати державу, бізнес-середовище та громадянське суспільство, сумлінно сплачувати податки, здійснювати ефективні інвестування в економіку держави, дотримуватися принципів чесної праці та конкуренції. Відповідальністю громадянського суспільства - контролювати владу, жити відповідно до принципів гідності та неухильно додержуватися Конституції України та законів України [17]. 
Відповідно до Постанови Кабінету Міністрів України від 03 березня 2021 р. № 179 «Про затвердження Національної економічної стратегії на період до 2030 року» одним з пріоритетних шляхів досягнення цілей Стратегії є розвиток громадянського суспільства, що передбачає виконання низки завдань, а саме:

- формування розуміння культурного розмаїття України та іiі регіонів, особливостей формування та реалізації громадянської ідентичності;

- створення умов для фінансової стійкості інститутів громадянського суспільства;

- створення умов для делегування повноважень органів державної влади та органів місцевого самоврядування інститутам громадянського суспільства [7].

Найбільш важливим документом, який направлений на процес розвитку громадянського суспільства став Указ Президента України від 26 лютого 2016 року № 68 «Про сприяння розвитку громадянського суспільства в Україні на 2016-2020 року» [18]. Основною метою ухвалення Стратегії зазначена «необхідність створення державою сприятливих умов для розвитку громадянського суспільства, різноманітних форм демократії участі, налагодження ефективної взаємодії громадськості 3 органами державної влади та органами місцевого самоврядування» [18]. У документі також зазначено, що саме Революція Гідності відкрила новий етап в історії розвитку громадянського суспільства, продемонструвала вплив громадськості на суспільно-політичні перетворення, стала поштовхом для оновлення та переформатування влади.

Реалізацію Стратегії передбачається здійснювати за такими стратегічними напрямами:

1. Створення сприятливих умов для формування та інституційного розвитку організацій громадянського суспільства.

2. Забезпечення ефективних процедур участі громадськості під час формування та реалізації державної, регіональної політики, вирішення питань місцевого значення;

3. Стимулювання участі організацій громадянського суспільства в соціально-економічному розвитку України. 

ці.

4. Створення сприятливих умов для міжсекторальної співпра-

5. Моніторинг та оцінка реалізації Стратегії покладалась на Координаційну раду сприяння розвитку громадянського суспільства, яка була створена Указом Президента України від 4 листопада 2016 року № 487/2016 [19].

Відповідно до Положення про Координаційну раду сприяння розвитку громадянського суспільства вона мала виконувати ряд завдань [19]:

- сприяти ефективній взаємодії державних органів, органів місцевого самоврядування 3 організаціями громадянського суспільства;

- формувати середовище для посилення ролі громадянського суспільства, залучення організацій громадянського суспільства до процесів формування та реалізації державної, регіональної політики, вирішення питань місцевого значення;

- привести національне законодавство у сфері розвитку громадянського суспільства у відповідність із європейськими стандартами;

- участь у проведенні просвітницько-інформаційних заходів, спрямованих на залучення представників організацій громадянського суспільства до участі у роботі державних органів та органів місцевого самоврядування.

Новим етапом розвитку громадянського суспільства та завершення процесу взаємодії державних органів, органів місцевого самоврядування з організаціями громадянського суспільства можна вважати ухвалення Кабінетом Міністрів України проекту Указу Президента України «Про Національну стратегію сприяння розвитку громадянського суспільства в Україні на 2021-2026 роки» [6].

Стратегією визначені чотири основні напрями:

1. Забезпечення ефективних процедур громадської участі у формуванні та реалізації державної політики на національному та регіональному рівнях.

2. Вирішення питань місцевого значення; створення сприятливих умов для формування та інституційного розвитку інститутів громадянського суспільства. 
3. Стимулювання участі інститутів громадянського суспільства в соціально-економічному розвитку України.

4. Створення сприятливих умов для міжсекторальної співпраці.

Очікуваними результатами виконання завдань зазначених напрямів вбачаються, зокрема: підвищення рівня обізнаності громадян про можливість створення інститутів громадянського суспільства, їх участі у прийнятті рішень органами влади та органами місцевого самоврядування; спрощення процедур реєстрації інститутів громадянського суспільства; посилення інституційної та ресурсної спроможності інститутів громадянського суспільства; розширення механізмів фінансової підтримки інститутів громадянського суспільства, можливостей їх участі у соціально-економічному житті, зокрема через поширення практик міжсекторальної співпраці; провадження інститутами громадянського суспільства благодійної та волонтерської діяльності тощо [6].

В обох документах, Указі Президента України від 26 лютого 2016 року № 68 «Про сприяння розвитку громадянського суспільства в Україні на 2016-2020 року» [18] та проекті Указу Президента України «Про Національну стратегію сприяння розвитку громадянського суспільства в Україні на 2021-2026 роки» [6], серед основних напрямів роботи прослідковується важливість налагодження комунікації з інститутами громадянського суспільства та інформаційне забезпечення, зокрема отримання зворотного зв'язку. Так, до Постанови Кабінету Міністрів України від 3 листопада 2010 р. № 996 «Про забезпечення участі громадськості у формуванні та реалізації державної політики» [8] вносяться зміни:

- у 2015 році внесено зміни про форми та механізми консультацій органів публічної влади з громадськістю. Так, є обов'язковими консультації з громадськістю у формі публічного громадського обговорення, електронних консультацій (безпосередні форми) та вивчення громадської думки (опосередкована форма). Консультації можуть проводитись одночасно. Важливо, що під час проведення електронних консультацій з громадськістю орган виконавчої влади оприлюднює на своєму офіційному веб-сайті та на урядовому веб-сайті 
«Громадянське суспільство і влада» повідомлення про проведення електронних консультацій, текст проекту акта, винесеного на обговорення. Тобто, можна говорити про відкритість і прозорість діяльності органів влади і готовність співпрацювати з інститутами громадянського суспільства, а громадянам захищати свої права та свободи [9].

- у 2019 році внесено зміни до п. 6 про обов'язкове проведення зустрічей з головами громадських рад, утворених при міністерствах, центральних органах виконавчої ради та держадміністраціях, не рідше, ніж 2 рази на рік. Такі зустрічі мають проводитися 3 метою реалізації державної політики та вирішення питань місцевого значення [10].

В контексті відкритості і прозорості діяльності органів влади ще в 2011 році Україна приєдналася до Ініціативи «Партнерство відкритий уряд», яку активно підтримують близько 80 країн. Перший план дій схвалений Розпорядженням Кабінету Міністрів України від 5 квітня 2012 р. № 220-р Про схвалення плану дій з впровадження в Україні Ініціативи «Партнерство «Відкритий Уряд» [12] і на $80 \%$ складався із заходів, які запропонували громадські експерти. Основною вимогою до уряду відповідно розпорядженню була постійна взаємодія з громадянами та інститутами громадянського суспільства, яка сприяла розвитку відкритого урядування з використанням новітніх інформаційно-комунікаційних технологій.

Другий план дій був схвалений у листопаді 2014 року РозпорядженнямКабінетуМіністрів України№ 1176-рПросхвалення плану дій 3 впровадження в Україні Ініціативи «Партнерство «Відкритий Уряд» на 2014-2015 рр [13]. Після консультацій 3 органами громадянського суспільства Кабінет Міністрів України визначив основні зобов'язання, які мали виконуватися у тісній співпраці органів виконавчої влади та громадянського суспільства:

- сприяння діяльності інститутів громадянського суспільства, їх участі у формуванні та реалізації державної політики;

- забезпечення доступу до публічної інформації;

- запобігання і протидія корупції;

- підвищення якості надання адміністративних та соціальних послуг; 
- впровадження технологій електронного урядування та розвиток електронної демократії [13].

У квітні 2015 року були внесені зміни до Закону України «Про доступ до публічної інформації» [2] з метою спрощення процедури доступу громадян до інформації. Зокрема, до п 10.1 закону про розміщення публічної інформації у формі відкритих даних. Публічна інформація у формі відкритих даних - це публічна інформація у форматі, що дозволяє іiі автоматизоване оброблення електронними засобами, вільний та безоплатний доступ до неї, a також iii подальше використання [2]. Тобто, розпорядники інформації зобов'язані надавати публічну інформацію у формі відкритих даних на запит, оприлюднювати і регулярно оновлювати iii на єдиному державному веб-порталі відкритих даних та на своїх веб-сайтах. А будь-яка особа може вільно копіювати, публікувати, поширювати, використовувати, у тому числі в комерційних цілях, у поєднанні з іншою інформацією або шляхом включення до складу власного продукту, публічну інформацію у формі відкритих даних з обов'язковим посиланням на джерело отримання такої інформації [2].

Наразі, за реалізацію державної політики у сфері відкритих даних відповідає Державне агентство 3 питань електронного урядування України, яке координує Кабінет Міністрів України. Цей центральний орган виконавчої влади забезпечує функціонування Єдиного державного вебпорталу відкритих даних (http://data.gov. ua/), який надає доступ до публічної інформації у формі відкритих даних. Державне агентство 3 питань електронного врядування розробляє та впроваджує стратегічні документи, рекомендації щодо відкритих даних, надає підтримку й консультації розпорядникам інформації, а також працює над удосконаленням роботи Єдиного державного порталу відкритих даних України, якістю наборів даних та їх використанням [4].

Для виконання Закону України «Про доступ до публічної інформації» Кабінет Міністрів України розробив та ухвалив Постанову № 835 «Про затвердження Положення про набори даних, які підлягають оприлюдненню у формі відкритих даних», яка 
визначила формати, структуру, вимоги, перелік наборів відкритих даних, що обов'язкові до оприлюднення розпорядниками публічної інформації [4].

У період з 2016 по 2018 роки уряд визнає, що роль інститутів громадянського суспільства постійно зростає. Громадські активісти, волонтери, благодійні організації роблять суттєвий внесок у підтримку громадян, які опинилися в складних життєвих ситуаціях та реалізацію соціально-економічних реформ в України. Розпорядженням Кабінету Міністрів України від 30 листопада 2016 р. № 909-р Про схвалення плану дій 3 впровадження в Україні Ініціативи «Партнерство «Відкритий Уряд» на 2016-2018 pp [14] передбачено підвищення якості та прозорості надання адміністративних послуг; надання адміністративних послуг в електронній формі; впровадження системи подання та оприлюднення декларацій осіб, уповноважених на виконання функцій держави або місцевого самоврядування; удосконалення механізму перевірки інформації про кінцевих бенефіціарних власників; забезпечення відкритості та прозорості здійснення публічних закупівель; забезпечення розвитку електронної демократії [14].

Основні завдання четвертого плану дій направлених на розвиток громадянського суспільства ухваленого Розпорядженням Кабінету Міністрів України від 18 грудня 2018 р. № 1088-р Про схвалення плану дій 3 впровадження в Україні Ініціативи «Партнерство «Відкритий Уряд» на 2018-2020 pp [15] є створення єдиної онлайнплатформи для взаємодії органів виконавчої влади з інститутами громадянського суспільства, запровадження пріоритетних електронних послуг, забезпечення учасників освітнього процесу сучасними електронними освітніми ресурсами і сервісами, забезпечення можливості проведення онлайн-перевірки документів про освіту тощо.

Логічним доповненням до впровадження механізму розміщення публічної інформації у формі відкритих даних $є$ рішення про електронні петиції відповідно до Закону України «Про звернення громадян» [3]. Зміни дозволяють громадянам подавати звернення до органів виконавчої влади в електронній формі. Також з'явилася 
можливість подавати електронні петиції до органів місцевого самоврядування, а за потреби Президенту України, Кабінету Міністрів України чи Верховній Раді. В умовах пандемії гострої респіраторної хвороби COVID-19 забезпечення цифрової трансформації основних галузей та сфер суспільного життя, доступу громадян до якісних та зручних публічних послуг, розвитку інструментів електронної демократії та відкритих даних є пріоритетом діяльності Уряду.

Завдяки діяльності уряду з'явилися відносно нові форми соціальної діяльності в Україні - громадський контроль, громадський моніторинг та публічні розслідування. Механізм громадського контролю використовується представниками інститутів громадянського суспільства для безпосереднього контролю за дотриманням прав та суспільних інтересів або виконанням владою своїх повноважень та відповідальності. Інститути громадянського суспільства та громадяни можуть самостійно проводити громадську експертизу за допомогою таких інструментів громадського контролю, як: звернення до органів державної влади, органів місцевого самоврядування, а також ï посадових та службових осіб; запит до власників публічної інформації, за допомогою яких вони можуть отримати правові акти та свої проекти. Проведення незалежних експертиз громадськими об'єднаннями на сьогодні $є$ найбільш часто використовуваною формою громадського контролю.

Наступною формою громадського контролю стало публічне розслідування. Це метод збору інформації, який передбачає роботу 3 численними джерелами, ретельний аналіз, порівняння, пошук суперечностей та прихованої інформації з метою оприлюднення даних, що становлять суспільний інтерес. Як приклад можна навести державне антикорупційне розслідування, спрямоване на обмеження конкуренції в державних закупівлях, неналежне використання державних коштів. Громадський аудит не часто використовується інститутами громадянського суспільства. У більш широкому розумінні це оцінка організації, системи, проекту, продукту, події чи особи на відповідність стандартам. Аудит може бути юридичним, фінансовим або технічним, якщо він стосується відповідних 
стандартів. Більш конкретно, аудит стосується фінансової звітності чи рахунків або, загальніше, фінансового управління [20].

Найпоширенішим і часто застосовуваним механізмом контролю $\epsilon$ громадський моніторинг. Така діяльність передбачає планомірний та систематичний збір інформації щодо конкретної проблеми чи діяльності державних органів, який здійснюється за прийнятою схемою 3 метою досягнення позитивних змін. Тобто ця система регулярного моніторингу та оцінки діяльності органів управління пов'язана $з$ досягненням їх цілей, виконанням завдань і програм, а також своєчасним виявленням та усуненням помилок та відхилень у роботі, контролем достовірності отриманих результатів.

Інститут громадянського суспільства використовує широкий спектр механізмів громадського контролю для оцінки дій та рішень влади у контексті європейської інтеграції. Однак рекомендації інституту громадянського суспільства часто ігноруються державними органами та органами місцевого самоврядування. Це можна пояснити відсутністю усталеної традиції взаємодії між ними, слабкістю самого інституту громадянського суспільства, а також небажанням влади бути чутливими до рекомендацій.

Висновки. Підсумовуючи аналіз нормативно-правового забезпечення розвитку громадянського суспільства, варто зауважити, що громадянське суспільство сприяє розвитку та зміцненню демократичних інститутів, передачі державою своїх владних повноважень певним громадським організаціям та органам самоврядування. Формування громадянського суспільства - одна з необхідних умов просування України по шляху проведення економічних, політичних і правових реформ, становлення правової держави в рамках іiі участі у європейській спільноті. Стрімкий розвиток громадянського суспільства в Україні почався після Революції Гідності 2013-14 роках і як наслідок прийняття низки законів, указів та стратегій, які націлені на забезпечення цифрової трансформації основних галузей та сфер суспільного життя, доступу громадян до якісних та зручних публічних послуг, розвитку інструментів електронної демократії та відкритих даних. У статті наголошено, що громадянське суспільство за своєю сутністю представляє собою добровільну взаємодію громадян, котрі прожива- 
ють на певній території, які мають комплекс прав та обов'язків, що дозволяють їм брати участь у розвитку держави. Але без створення державою умов, співпраці та підтримки, зокрема на законодавчому рівні, розвиток громадянського суспільства стане неможливим.

\section{Стаття надійшла до редакції: 12.07.21}

\section{LEGAL AND REGULATORY FRAMEWORK FOR THE DEVELOPMENT OF CIVIL SOCIETY IN UKRAINE}

Tetiana Akimova, PhD in Public Administration, Petro Mohyla Black Sea National University, Mykolaiv, Ukraine

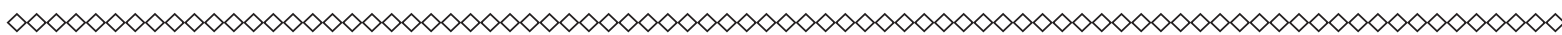

The issues of regulatory and legal support for the civil society development in Ukraine are studied in the article. Important documents that contributed to the development of civil society are analyzed.

The author revealed the concept of civil society. The current existing approaches to understanding civil society are considered. The supporters of the first approach, a broad one, perceive civil society as a certain stage of development of any society. The second approach considers civil society as a complex of all non-governmental social relations. The main components in the civil society system and the main roles of civil society organizations are mentioned. They are: development services, influence on politics by means of dialogue and advocacy, human rights protection and democratization.

It is noted that the rapid development of civil society in Ukraine began after the Revolution of Dignity in 2013-2014. An example of citizens'initiative that emerged during the Revolution of Dignity was the Reanimation Package of Reforms. It was determined that the top 3 tasks of non-governmental organizations in Ukraine were government control, civic education, support and stimulation of reforms.

The article examines the process of civil society development in the legislative context. The Strategy of Sustainable Development 
"Ukraine-2020", the National Economic Strategy for the period up to 2030, the "National Strategy for Promoting Civil Society Development in Ukraine for 2021-2026" and others are analyzed. It has been proven that the main areas of work include the importance of establishing communication with civil society institutions and information support, including feedback. The main prerequisite for the process of civil society development is a social contract between government, business and civil society where each party has its own area of responsibility.

Key words: public administration, civil society, legal mechanisms, civil society organizations.

\section{Received: 12.07.21}

\section{References}

1. Solonenko, I., Khoroljsjkyj, R., Shapovalova, N., \& Lacyba, M. (2008). Ghromadjansjke suspiljstvo v Ughodi pro asociaciju mizh Ukrajinoju ta JeS [Civil society in the Association Agreement between Ukraine and the $E U]$. Kyiv: Ghromadsjka rada pry Ukrajinsjkij chastyni Komitetu z pytanj spivrobitnyctva mizh Ukrajinoju ta JeS [in Ukrainian].

2. Zakon Ukrajiny Pro dostup do publichnoji informaciji vid 13.01.2011 r. No 2939-VI [Law of Ukraine On Access to Public Information dated 13.01.2011 No 2939-VI]. (n.d.). zakon.rada.gov.ua. Retrieved from https:// zakon.rada.gov.ua/laws/show/2939-17NoText [in Ukrainian].

3. Zakon Ukrajiny Pro zvernennja ghromadjan vid 02.10.1996 No 393/96 VR [Law of Ukraine On Public Appeal of October 2, 1996 No 393/96 of the Verkhovna Rada]. (n.d.). zakon.rada.gov.ua. Retrieved from https://zakon.rada. gov.ua/laws/show/393/96-\%D0\%B2\%D1\%80 [in Ukrainian].

4. Metodychni rekomendaciji pidghotovleni Derzhavnym aghentstvom $\mathrm{z}$ pytanj elektronnogho urjaduvannja Ukrajiny $\mathrm{z}$ zaluchennjam ekspertiv proghramy «Prozoristj ta pidzvitnistj $u$ derzhavnomu upravlinni ta poslughakh» [Methodical recommendations prepared by the State Agency for e-Government of Ukraine to involve experts in the progress of «Transparency and subconsciousness in public administration and assistance»]. (n.d.). 
data.gov.ua. Retrieved from https:/data.gov.ua/uploads/files/2018-08-11104353.234698Recomendation.pdf [in Ukrainian].

5. Ukaz Prezydenta Ukrajiny Pro Strateghiju derzhavnoji polityky spryjannja rozvytku ghromadjansjkogho suspiljstva $\mathrm{V}$ Ukrajini ta pershocherghovi zakhody shhodo jiji realizaciji vid 24 bereznja 2012 roku No 212/2012 [Decree of the President of Ukraine On the Strategy of State Policy aimed at the development of civil society in Ukraine and priority measures related to implementation of March 24, 2012 No 212/2012]. (n.d.). zakon3. rada.gov.ua. Retrieved from http://zakon3.rada.gov.ua/laws/show/212/2012 [in Ukrainian].

6. Proekt Ukazu Prezydenta Ukrajiny Pro Nacionaljnu strateghiju spryjannja rozvytku ghromadjansjkogho suspiljstva v Ukrajini na 2021 - 2026 roky [Draft Decree of the President of Ukraine On the national strategy for the development of the Russian community of civil society in Ukraine for 2021 2026]. (n.d.). kmu.gov.ua. Retrieved from https://www.kmu.gov.ua/news/uryadshvaliv-proekt-nacionalnoyi-strategiyi-spriyannya-rozvitku-gromadyanskogosuspilstva-v-ukrayini-na-2021-2026-roki [in Ukrainian].

7. Postanova KMU Pro zatverdzhennja Nacionaljnoji ekonomichnoji strateghiji na period do 2030 roku vid 03 bereznja 2021 r. No 179 [Resolution of the Cabinet of Ministers On confirmation of the national economic strategy for the period up to 2030 of March 3, 2021 No 179]. (n.d.). kmu.gov.ua. Retrieved from https://www.kmu.gov.ua/npas/pro-zatverdzhennya-nacionalnoyieko-a179 [in Ukrainian].

8. Postanova Kabinetu Ministriv Ukrajiny «Pro zabezpechennja uchasti ghromadsjkosti u formuvanni ta realizaciji derzhavnoji polityky» vid 3 lystopada 2010 r. No 996 [Resolution of the Cabinet of the Ministry of Ukraine On ensuring public participation in the formation and implementation of public policy of November 3, 2010 No 996]. (n.d.). zakon3.rada.gov.ua. Retrieved from https://zakon.rada.gov.ua/laws/show/996-2010-\%D0\%BFNoText [in Ukrainian].

9. Postanova Kabinetu Ministriv Ukrajiny «Pro vnesennja zmin do postanov Kabinetu Ministriv Ukrajiny vid 5 lystopada 2008 r. No 976 ta vid 3 lystopada 2010 r. No 996 vid 8 kvitnja 2015 r. No 234 [Resolution of the Cabinet of Ministers of Ukraine On Amendments to the Resolution of the Cabinet of Ministers of Ukraine of November 5, 2008 No 976 and type of November 3, 2010 No 996 of April 8, 2015 No 234]. (n.d.). zakon3.rada.gov.ua. Retrieved 
from https://zakon.rada.gov.ua/laws/show/234-2015-\%D0\%BFNon44 [in Ukrainian].

10. Postanova Kabinetu Ministriv Ukrajiny Zminy, shho vnosjatjsja do postanovy Kabinetu Ministriv Ukrajiny vid 3 lystopada 2010 r. No 996 vid 24 kvitnja 2019 r. No 353 [Resolution of the Cabinet of Ministers of Ukraine Amendments submitted to the Resolution of the Cabinet of Ministers of Ukraine of November 3, 2010 No 996 of April 24, 2019 No 353]. (n.d.). zakon3. rada.gov.ua. Retrieved from https://zakon.rada.gov.ua/laws/show/353-2019$\%$ D0\%BFNoText [in Ukrainian].

11. Jablonsjkyj, V.M., Voznjuk, P.F., \& Ghorjelov, D.M. (et. al.). (2015). Rozvytok ghromadjansjkogho suspiljstva v Ukrajini [Development of civil society in Ukraine]. O.A. Kornijevsjkii, M.M. Rozumnyi (Eds.). Kyiv: NISD. Retrieved from https://niss.gov.ua/sites/default/files/2015-11/ Korniyevskiy_12_11-58701.pdf [in Ukrainian].

12. Rozporjadzhennja Kabinetu Ministriv Ukrajiny Pro skhvalennja planu dij z vprovadzhennja v Ukrajini Iniciatyvy «Partnerstvo «Vidkrytyj Urjad» vid 5 kvitnja 2012 r. No 220-r [Order of the Cabinet of Ministers of Ukraine On approval of the action plan with the implementation of the Open Government «Partnership «Initiative in Ukraine» of April 5, 2012 No 220-r]. (n.d.). zakon. rada.gov.ua. Retrieved from https://zakon.rada.gov.ua/laws/show/220-2012$\%$ D1\%80NoText [in Ukrainian].

13. Rozporjadzhennja Kabinetu Ministriv Ukrajiny Pro skhvalennja planu dij z vprovadzhennja v Ukrajini Iniciatyvy «Partnerstvo «Vidkrytyj Urjad» na 2014-2015 roku vid 26 lystopada 2014 r. No 1176-r [Order of the Cabinet of Ministers of Ukraine On planning the plan for implementation in Ukraine of the Initiative «Partnership «Opening of the Government» for 2014-2015 of November 26, 2014 No 1176-r]. (n.d.). zakon.rada.gov.ua. Retrieved from https://zakon.rada.gov.ua/laws/show/1176-2014-\%D1\%80NoText [in Ukrainian].

14. Rozporjadzhennjam Kabinetu Ministriv Ukrajiny Pro skhvalennja planu dij z vprovadzhennja v Ukrajini Iniciatyvy «Partnerstvo «Vidkrytyj Urjad» na 2016-2018 rr vid 30 lystopada 2016 r. No 909-r [Order of the Cabinet of Ministers of Ukraine On planning the plan for implementation in Ukraine of the Open Government Partnership Initiative for 2016-2018 of November 30, 2016 No 909-r]. (n.d.). zakon.rada.gov.ua. Retrieved from https://zakon.rada. gov.ua/laws/show/909-2016-\%D1\%80NoText [in Ukrainian]. 
15. Rozporjadzhennjam Kabinetu Ministriv Ukrajiny Pro skhvalennja planu dij z vprovadzhennja v Ukrajini Iniciatyvy «Partnerstvo «Vidkrytyj Urjad» na 2018-2020 rr vid 18 ghrudnja 2018 r. No 1088-r [Order of the Cabinet of Ministers of Ukraine On approval of the action plan with the implementation in Ukraine of the Open Government Partnership Initiative for 2018-2020 of December 18, 2018 No 1088-r]. (n.d.). zakon.rada.gov.ua. Retrieved from https://zakon.rada.gov.ua/laws/show/1088-2018-\%D1\%80NoText [in Ukrainian].

16. Soljar, S. (2013). Ghromadjansjke suspiljstvo: zaghaljnoteoretychni pidkhody do vyznachennja [Civil society: general theoretical approaches to the definition]. Visnyk Akademiji pravovykh nauk Ukrajiny - Bulletin of the Academy of Legal Sciences of Ukraine, 1, (pp. 271-279). Retrieved from http://nbuv.gov.ua/UJRN/vapny_2013_1_29 [in Ukrainian].

17. Ukaz Prezydenta Ukrajiny Pro Strateghiju stalogho rozvytku «Ukrajina - 2020» vid 12.01.2015 No 5/2015 [Decree of the President of Ukraine of 12.01.2015 No 5/2015 On the strategy of sustainable development «Ukraine - 2020»]. (n.d.). zakon.rada.gov.ua. Retrieved from https://zakon. rada.gov.ua/laws/show/5/2015NoText [in Ukrainian].

18. Ukaz Prezydenta Ukrajiny Pro spryjannja rozvytku ghromadjansjkogho suspiljstva v Ukrajini na 2016-2020 roky vid 26 ljutogho 2016 roku No 68 [Decree of the President of Ukraine On the introduction of civil society development in Ukraine for 2016-2020, valid until February 26, 2016, No 68]. (n.d.). zakon.rada.gov.ua. Retrieved from https://zakon.rada.gov.ua/laws/show/ $\mathrm{ru} / 68 / 2016$ NoText [in Ukrainian].

19. Ukaz Prezydenta Ukrajiny Pytannja Koordynacijnoji rady spryjannja rozvytku ghromadjansjkogho suspiljstva vid 4 lystopada 2016 roku No 487/2016 [Decree of the President of Ukraine Issues of coordination work aimed at the development of civil society of November 4, 2016 No 487/2016]. (n.d.). zakon.rada.gov.ua. Retrieved from https://zakon.rada.gov.ua/laws/ show/487/2016NoText [in Ukrainian].

20. Ukrajina na ostannjomu misci za integhracijeju z JeS sered pidpysantiv asociaciji [Ukraine last month for integration with the EU through the association of signatures]. (n.d.). www.eurointegration.com.ua. Retrieved from http:/www.eurointegration.com.ua/news/2014/11/21/7028016/ [in Ukrainian].

21. Resolution adopted by the General Assembly «Transforming our world: the 2030 Agenda for Sustainable Development» on 25 September 2015 
[Resolution adopted by the General Assembly, «Transforming our world: the 2030 Agenda for Sustainable Development» on 25 September 2015]. (n.d.). www.ua.undp.org. Retrieved from https://www.ua.undp.org/content/ukraine/ uk/home/library/sustainable-development-report/the-2030-agenda-forsustainable-development.html [in English].

22. Edwards, M. (Ed.). (2011). Introduction: Civil society and the geometry of human relations. New York: The Oxford Handbook of Civil Society, Oxford University Press. Retrieved from https://dl.icdst.org/pdfs/files2/32f3e0e50e024 efde2bbec5144e4aa57.pdf [in English].

23. Kresina, I., Skrypnjuk, O., \& Kovalenko, A. Derzhava ta ghromadjansjke suspiljstvo v Ukrajini: problemy vzajemodiji [State and public society in Ukraine: problems of reciprocity]. I.O. Kresinoji (Ed.). Kyiv: Loghos [in Ukrainian].

24. Tjahja, N., Meyer T., Shahin J. (2021). What is civil society and who represents civil society at the IGF? An analysis of civil society typologies in internet governance. Telecommunications Policy, (Vol. 45), 6. Retrieved from https://doi.org/10.1016/j.telpol.2021.102141 [in English].

25. Antonova, L. Shtyrov O., (2020). Komunikatyvni tekhnolohii v protsesi vzaiemodii orhaniv publichnoi vlady z instytutamy hromadianskoho suspilstva [Communicative technologies in the process of interaction of public authorities with institutions of civil society], Derzhavne upravlinnya: udoskonalennya ta rozvytok, (vol. 6), Retrieved from www.dy.nayka.com.ua/?op=1\&z=1899. DOI: 10.32702/2307-2156-2020.6.1 [in Ukrainian].

\section{Відомості про автора / Information about the Author}

Акімова Тетяна Юріївна: Чорноморський національний університет імені Петра Могили: вул. 68 десантників, 10, Миколаїв, 54003, Україна.

Tetiana Akimova: Petro Mohyla Black Sea National University: 68 Desantnykiv str. 10, Mykolaiv, 54003, Ukraine

\section{ORCID. ORG./ 0000-0002-4935-290X}

\section{E-mail: tanjaskiba@gmail.com}

